University of Nebraska - Lincoln

DigitalCommons@University of Nebraska - Lincoln

Agronomy \& Horticulture -- Faculty Publications

Agronomy and Horticulture Department

2-8-1963

\title{
Glucosides of Coumarinic and o-Coumaric Acids in the Tonka Bean
}

Francis A. Haskins

University of Nebraska-Lincoln, fhaskins@neb.rr.com

H. J. Gorz

University of Nebraska-Lincoln

Follow this and additional works at: https://digitalcommons.unl.edu/agronomyfacpub

Part of the Plant Sciences Commons

Haskins, Francis A. and Gorz, H. J., "Glucosides of Coumarinic and o-Coumaric Acids in the Tonka Bean" (1963). Agronomy \& Horticulture -- Faculty Publications. 156.

https://digitalcommons.unl.edu/agronomyfacpub/156

This Article is brought to you for free and open access by the Agronomy and Horticulture Department at DigitalCommons@University of Nebraska - Lincoln. It has been accepted for inclusion in Agronomy \& Horticulture -Faculty Publications by an authorized administrator of DigitalCommons@University of Nebraska - Lincoln. 
Table 1. Contents of coumarinic and $o$-coumaric acids in various tissues of the tonka bean.

\begin{tabular}{|c|c|c|c|c|c|}
\hline \multirow{3}{*}{ Tissue } & \multirow{3}{*}{$\begin{array}{c}\text { No. of } \\
\text { extracts } \\
\text { analyzed }\end{array}$} & \multicolumn{4}{|c|}{ Range in content (\% of dry wt.) } \\
\hline & & \multicolumn{2}{|c|}{ Coumarinic acid } & \multicolumn{2}{|c|}{$o$-Coumaric acid } \\
\hline & & Free* & Bound & Free & Bound \\
\hline \multicolumn{6}{|c|}{ Immature fruit } \\
\hline Exocarp & 2 & 0.01 to 0.02 & 0.01 to 0.10 & 0 & 0.39 to 0.44 \\
\hline Cotyledon & 4 & 1.12 to 8.99 & 0 to 4.00 & 0 & 0 to 0.17 \\
\hline Cotyledon & 5 & $\begin{array}{r}\text { Matur } \\
0.62 \text { to } 6.15\end{array}$ & 0.06 to 6.79 & 0 & 0.11 to 0.23 \\
\hline \multicolumn{6}{|c|}{ Seedling leaves } \\
\hline First $\dagger$ & 2 & 0.11 to 0.17 & 2.10 to 2.80 & 0 & 2.14 to 2.25 \\
\hline Third $\dagger$ & 2 & 0.15 to 0.28 & 2.12 to 2.23 & 0 & 0.45 to 0.65 \\
\hline Fifth $\dagger$ & 1 & 0.27 & 0.81 & 0 & 0.15 \\
\hline
\end{tabular}

marinic acid (cis-o-hydroxycinnamic acid). He concluded that no coumarinyl glucoside was present. In recent work, the $\beta$-glucosides of both coumarinic acid and $o$-coumaric acid (trans-o-hydroxycinnamic acid) were implicated as coumarin precursors in sweetclover (Melilotus alba Desr.) (3, 4 ) and possibly in sweetgrass [Hierochloe odorata (L.) Beauv.] (5), and the "bound coumarin" of sweetclover was identified as coumarinyl glucoside $(6,7)$. Although the presence of glycosidically bound coumarinic and $o$ coumaric acids in tonka bean leaves may be inferred from the recent studies of Griffiths (8), the occurrence of these glycosides remains uncertain because the paper contains information only on acid-hydrolyzed leaf extracts. We now present evidence indicating that the $\beta$ glucosides of coumarinic and $o$-coumaric acids exist in seedling leaves and also in the fruit of the tonka bean.

Three tonka bean seedlings were grown in soil under standard cool white fluorescent lights in the laboratory. Aqueous extracts of seedling leaves, various portions of immature fruits, and cotyledons of mature fruits were prepared by dropping the respective tissue samples into boiling water and immediately autoclaving for 20 minutes. This procedure minimized the action of endogenous glucosidases during extraction. Aliquots of the extracts were assayed fluorometrically for free coumarinic and $o$-coumaric acids, and other aliquots were hydrolyzed by autoclaving for 45 minutes in $2.25 \mathrm{~N} \mathrm{NaOH}$ before assay, to provide estimates of total levels of the two acids. Values for the bound compounds were calculated by difference. The assay procedure was essentially the one used in studies on sweetclover (9).

As shown in Table 1, the cis isomer of $o$-hydroxycinnamic acid predomi- nated in cotyledons of both immature and mature fruits, but in the exocarp of the immature fruits the trans isomer was predominant. Less pronounced differences between levels of the two isomers were observed in seedling-leaf extracts. The trans isomer was not detected in the free form in any of the extracts, but both free coumarin (the lactone form of coumarinic acid) and bound coumarinic acid were abundant in extracts of cotyledons and seedling leaves. Extracts obtained from immature cotyledons within a few days after harvest of the fruits were comparatively low in content of free coumarin and rich in bound coumarinic acid. Similarly, extracts of cotyledons from fruits which apparently matured naturally were relatively low in free coumarin. However, extracts of cotyledons from immature fruits stored under refrigeration for several weeks, or from dried fruits which appeared to have been harvested before full maturity, were high in content of free coumarin. These observations suggest the possibility that the presence of large amounts of free coumarin may be an artifact resulting from the extraction procedure or from unnatural ripening or storage conditions. Similar findings regarding the presence of free coumarin in sweetclover were recently reported $(7,10)$.

In the tonka bean fruits, coumarinic and $o$-coumaric acids were not confined to the exocarp and cotyledons. However, interfering fluorescent substances were present in aqueous extracts of the mesocarp and endocarp, and available data on these parts are less reliable than the data presented in the table.

In chromatographic tests employing the four solvents described by Kosuge (6), $R_{F}$ values observed for the bound forms of coumarinic acid and $o$ coumaric acid in tonka bean extracts were identical to values for authentic to determine whether coumarin occurs in nature as the $\beta$-glucoside of cou- 
samples of the $\beta$-glucosides of coumarinic acid and $o$-coumaric acid, respectively. The action of a preparation of $\beta$-glucosidase from almonds (Mann Research Laboratories) on the bound compounds furnished further evidence that the compounds were $\beta$-glucosides. Both bound compounds were hydrolyzed by the almond preparation; and, in agreement with reports of other workers $(3,5)$, the trans compound was hydrolyzed more rapidly than the cis isomer.

An active $\beta$-glucosidase was detected in extracts of tonka bean leaves and cotyledons. Unlike the almond $\beta$ glucosidase, however, the tonka bean enzyme rapidly hydrolyzed coumarinyl glucoside and was essentially inert toward o-coumaryl glucoside. In its specificity for the cis glucoside, the tonka bean enzyme resembled sweetclover $\beta$ glucosidase (3).

The occurrence of the $\beta$-glucosides of coumarinic acid and $o$-coumaric acid and the presence of a glucosidase specific for the cis glucoside indicate that in the tonka bean, as in sweetclover (3), coumarin is synthesized through the conversion of $o$-coumaryl glucoside to coumarinyl glucoside which under suitable conditions may be hydrolyzed to yield coumarinic acid. Spontaneous lactonization of coumarinic acid then produces coumarin (11).

F. A. Haskins

H. J. Gorz

Department of Agronomy, University

of Nebraska, and Agricultural Research Service, U.S. Department of

Agriculture, Lincoln

References and Notes

1. J. R. Clopton, J. Agr. Food Chem. 6, 457 (1958).

2. H. Lutzmann, Ber. Deut. Chem. Ges. 73b, 632 (1940).

3. T. Kosuge and E. E. Conn, J. Biol Chem. T. Kosuge and 1617 (1961).

4. J. R. Stoker and D. M. Bellis, ibid. 237, 2303 (1962).

5. S. A. Brown, Can. J. Biochem. Physiol. 40 , 607 (1962).

6. T. Kosuge, Arch. Biochem. Biophys. 95, 211 (1961).

7. G. Kahnt and W. J. Schön, Angew. Botan. 36, 33 (1962).

8. L. A. Griffiths, J. Exptl. Botany 13, 169 (1962) 9. F. A. Haskins and H. J. Gorz, Biochem. Biophys. Res. Commun. 6, 298 (1961).

10. , Crop Sci. 1, 320 (1961).

11. Cooperative investigations of the Crops Research Division, U.S. Agricultural Research Service, and the Nebraska Agricultural Experiment Station. Research supported in part by the National Science Foundation (grant No. G13182). Published with the approval of the director as Paper No. 1307, Journal Series, Nebr. Agr. Exp. Sta. Tonka bean fruits were generously furnished by Dr. H. J. Teas, Puerto Rico Nuclear Center, and N. Almeyda, Federal Exp. Sta., Mayaguez, Puerto Rico. Futhentic samples of coumarinyl Rico. Authentic samples of coumarinyl glucoside and o-coumaryl glucoside were supplied by Dr. The technical assistance of California, Davis is gratefully acknowledged.

19 November 1962

8 FEBRUARY 1963 